\title{
ANALISIS FAKTOR - FAKTOR YANG MEMPENGARUHI KONSUMSI BERAS DI PROVINSI BALI
}

\author{
I Putu Danendra Putra ${ }^{1}$ \\ I Gede Wardana ${ }^{2}$
}

\author{
${ }^{1,2}$ Magister Ilmu Ekonomi Program Pascasarjana Fakultas Ekonomi dan Bisnis \\ Universitas Udayana \\ e-mail: danendra_putra69@yahoo.co.id
}

\begin{abstract}
ABSTRAK
Beras merupakan kebutuhan pokok dan utama masyarakat Bali sebagai sumber karbohidrat utama. Konsumsi beras di Provinsi Bali terus meningkat setiap tahunnya namun tidak diimbangi dengan peningkatan produksi beras. Penelitian ini bertujuan untuk mengetahui bagaimana pengaruh harga beras, jumlah penduduk, jumlah kunjungan wisatawan domestik dan jumlah kunjungan wisatawan mancanegara terhadap konsumsi beras serta bagimana Produk Domestik Regional Bruto (PDRB) memoderasi pengaruh harga beras dan jumlah penduduk terhadap konsumsi beras. Sumber data yang digunakan dalam penelitian ini yaitu data sekunder yang didapat dari Badan Pusat Statistik Provinsi Bali, Dinas Pertanian Provinsi Bali, Dinas Pariwisata Provinsi Bali dan dinas terkait lainnya. Analisis yang digunakan dalam penelitian ini adalah analisis deskritif dan analisis asosiatif menggunakan analisis regeresi linier berganda, analisis variabel moderating. Hasil analisis menunjukan jumlah penduduk, jumlah kunjungan wisatawan domestik dan jumlah kunjungan wisatawan mancanegara berpengaruh positif dan signifikan terhadap konsumsi beras, sedangkan harga beras berpengaruh negatif namun tidak signifikan terhadap konsumsi beras Provinsi Bali tahun 1983-2016. PDRB secara signifikan memperkuat pengaruh harga beras dan jumlah penduduk terhadap konsumsi beras Provinsi Bali tahun 1983-2016.

Kata Kunci: Harga beras, jumlah penduduk, jumlah kunjungan wisatawan dan konsumsi beras
\end{abstract}

\begin{abstract}
Rice is a basic and primary requirement of Balinese people as the main source of carbohydrates. Consumption rice in Bali Province continues to increase every year but not offset by increased rice production. This study aims to determine how the influence of rice prices, the number of residents, the number of visits of domestic tourists and the number of foreign tourists visiting the consumption of rice and bagimana Gross Regional Domestic Product (PDRB) moderate the influence of rice prices and the population of rice consumption. Sources of data used in this study are secondary data obtained from the Central Bureau of Statistics Bali Province, Bali Provincial Agriculture Office, Bali Provincial Tourism Office and other related offices. The analysis used in this research is descriptive analysis and associative analysis using multiple linear regeresis analysis, moderating variable analysis. The result of analysis shows the number of population, the number of domestic tourist visit and the number of foreign tourist visit have positive and significant influence to the consumption of rice, while the price of rice have negative but insignificant effect to the consumption of Bali Provincial rice in 1983-2016. GRDP significantly strengthens the influence of rice prices and population on rice consumption of Bali Province in 1983-2016.
\end{abstract}

Keywords: $\quad$ Rice price, population, tourist visit and rice consumption 


\section{Latar Belakang}

Konsmsi akan pangan tidak dapat dipisahkan dari kehidupan masyarakat karena merupakan kebutuhan pokok yang pemenuhannya tidak dapat ditunda. Deklarasi Sustinable Development Goal's (SDGs) pada 25 September 2015 di New York, Amerika Serikat menyepakati penurunan jumlah penduduk lapar harus mencapai $100 \%$ pada tahun 2030, serta pola produksi dan konsumsi pangan yang berkelanjutan (Mickael, 2015). FAO (2008) dalam Suryana (2008) menyatakan bahwa, pangan merupakan manusia yang paling dasar, dimana pemerintah menjaga ketersediaan pangan yang layak. Terjaminnya ketersediaan pangan serta mudah didapat dan terjangkau oleh daya beli masyarakat merupakan faktor penting dalam mensukseskan pembangunan nasional. Menurut Najib Muhammad (2008) pangan menyangkut kebutuhan manusia yang paling asasi, maka dapat dikatakan bahan pangan mempunyai posisi strategis, politis, ekonomis, dan emosional, sehingga keberadaan pangan yang relatif dapat ditemui kapan dan di mana saja, akan memberi andil cukup besar dalam menjaga stabilitas ekonomi, politik, dan sosial.

Masalah beras merupakan masalah yang perlu diperhatikan, disaat bangsa Indonesia mengalami krisis yang cukup membebani rakyat golongan menengah ke bawah yang merupakan mayoritas rakyat Indonesia saat ini. Peranan pemerintah dengan lembaga penyanggah (BULOG) yang sebenarnya bertujuan untuk memantau, menstabilkan harga dan pasokan beras di pasar ternyata belum mampu berperan secara signifikan akibat lemahnya kemampuan manajerial pengelola sehingga sering terjadi defisit ketersediaaan beras sehingga 
menyebabkan gejolak harga di pasar yang cukup meresahkan masyarakat (Husni, 2004). Melalui otonomi daerah diharapkan setiap daerah mampu berinovasi dan melakukan perubahan dalam upaya membangun ketahanan pangan yang berkelanjutan sehingga swasembada pangan dapat tercapai. Berbagai upaya dapat dilakukan diantaranya melaui peningkatan produksi maupun diversifikasi. Setiap daerah diharapkan mampu melaksanakan dengan baik program pencapaian swasembada pangan, dengan demikian pencapaian swasembada pangan di tingkat nasional dapat diwujudkan.

Konsumsi beras di Provinsi Bali pada tahun 1983 mencapai 268.908,90 ton dan terus meningkat setiap tahunnya, dan pada tahun 2016 konsumsi beras mencapai 468.694,79 ton, sehingga sejak tahun 1983-2016 peningkatan konsumsi beras mencapai 80\%. Produksi beras Provinsi Bali pada tahun 2016 hanya 448.844.46 ton. Kecenderungan menurun pada produksi beras dari tahun 19832016 mencapai sebesar 52.102.14 ton atau 10,4 persen. Penurunan produksi beras di Bali menyebabkan adanya defisit produksi beras sebesar $19.850,32$ ton pada tahun 2016. Peningkatan konsumsi beras yang terus meningkat setiap tahunnya harus dapat diketahui berbagai faktor yang mempengaruhinya. Hal ini bertujuan untuk dapat menghitung konsumsi beras yang akurat sehingga tidak terjadi gejolak harga beras serta kelangkaan ketersediaan beras di Bali sehingga kestabilan pasar beras dapat terjaga.

Meningkatnya konsumsi beras dan terus menurunnya produksi beras menyebabkan harga beras terus meningkat (Afrianto, 2010). Konsumsi beras yang terus meningkat disebabkan oleh semakin meningkatnya jumlah penduduk (Nani, 
2009). Provinsi Bali sebagai destinasi wisatawa berhasil mendatangkan wisatawan yang banyak, sehingga akan terdapat tambahan konsumsi kebutuhan pokok di Bali, khususnya beras sebagai sumber karbohidrat (Angappapillai, 2013). Bersasarkan pemaparan permasalahan tersebut maka akan diteliti tentang analisis faktot - faktor yang mempengaruhi konsumsi beras di Provinsi Bali.

\section{Kajian Pustaka}

Konsumsi merupakan barang dan jasa yang diperlukan oleh masyarakat untuk dapat memenuhi berbagai kebutuhannya (Mankiew, 2007). 90 persen dari penduduk Indonesia mengkonsumsi beras sebagai makanan pokok. Beras jika dibandingkan dengan jenis makanan pengganti lainnya yang serupa, beras memiliki kandungan nilai gizi lebih baik jika. Oleh karena itu, komoditas beras sangat diperlukan dalam upaya pemenuhan gizi masyarakat yang umumnya belum dapat dipenuhi oleh masyarakat secara layak (Amang, 1999).

Berdasarkan studi yang dilakukan oleh Sari (2007), beras merupakan makanan pokok penduduk Indonesia dan masih sulit untuk digantikan oleh bahan pangan lainnya secara utuh, sehingga ketika harga beras terus meningkat, masyarakat akan tetap berusaha untuk membeli beras guna dapat memenuhi kebutuhannya terhadap beras meskipun harus mengurangi jumlah konsumsi berasnya. Beras merupakan kebutuhan yang diperlukan oleh 90 persen masyarakat, oleh sebab itu pasar beras seharusnya lebih mendapat perhatian karena menyangkut hajat hidup banya orang, khususnya terkait dengan ketersediaannya, karena akan mempengaruhi harga sehingga tidak terjadi 
monopoli atau permainan harga yang dapat mengganggu kestabilan konsumsi beras di pasar.

Dalam rangka pembangunan di suatu wilayah, dapat memanfaatkan penduduk sebai sumber daya. Penduduk yang jumlahnya kian meningkat tidak selalu dipandang sebagi masalah, jika dapat diberdayakan dengan baik, peningkatan jumlah penduduk dapat menjadi potensi pasar bagi produksi yang dihasilkan jika dipandang dari sisi permintaan, tentunya hal ini dapat terwujud jika pertumbuhan penduduk tersebut diiringi dengan peningkatan daya beli. Menurut Mangahas (Benu, 1996), jumlah penduduk merupakan faktor yang paling dominan yang mempengaruhi kenaikan dalam permintaan produk pertanian. Sehingga pada daerah yang penduduknya mengkonsumsi beras sebagai pangan pokok, maka semakin meningkatnya jumlah penduduk maka permintaan terhadap beras juga akan terus mengalami peningkatan.

Provinsi Bali sebagai destinasi wisata telah mendatangkan wisatawan dalam jumlah yang besar. Sujai (2011) mengatakan beberapa sektor yang langsung terlibat dalam kegiatan pariwisata seperti restoran, perdagangan eceran, agen perjalanan, operator wisata dan hotel. Hotel dan restoran merupakan sarana penting dalam menunjang kegiatan wisata, karena hal tersebut terkait dengan konsumsi atas makanan dan tempat tinggal untuk wisatawan. Menurut Angappapillai (2013) konsumsi atas pangan atau makanan oleh wisatawan akan memberi dampak langsung terhadap konsumsi agregat, khususnya makanan pokok, jika dikaitkan dengan wisatawan domestik maka konsumsi beras akan meningkat seiring dengan peningkatan jumlah wisatawan. 
I Putu Danendra Putra, dan I Gede Wardana. A nalisis Faktor-Faktor ...

Susanti (2000) menyatakan semakin besar Produk Domestik Regional Bruto (PDRB) di suatu daerah akan menunjukan semakin meningkat juga rata-rata konsumsi untuk barang dan jasa di daerah tersebut, khususnya untuk konsumsi pangan pokok. Meningkatnya kesejahteraan masyarakat yang dicerminkan dari PDRB tentunya mendorong perubahan pola konsumsi masyarakat ke arah yang lebih baik. Peningkatan pendapatan dapat meningkatkan konsumsi pangan pokok di masyarakat walaupun harganya cenderung meningkat. Karena pangan pokok merupakan kebutuhan utama manusia untuk dapat bertahan hidup, tentunya harus tetap terjamin ketersediaann dan harganya.

\section{Kerangka Konsep Penelitian}

Pada bagian ini akan digambarkan keterkaitan antar variabel penelitian untuk memperjelas variabel mana yang berfungsi sebagai variabel independen, dependen dan moderating. Kerangka konsep penelitian berikut ini memperlihatkan keterkaitan variabel independen dan variabel dependen, dimana variabel dependent adalah konsumsi beras, sementara variabel independen meliputi harga beras, jumlah penduduk, jumlah kunjungan wisatawan domestik, jumlah kunjunan wisatawan mancanegara dan pendapatan perkapita yang merupakan variabel moderating. 


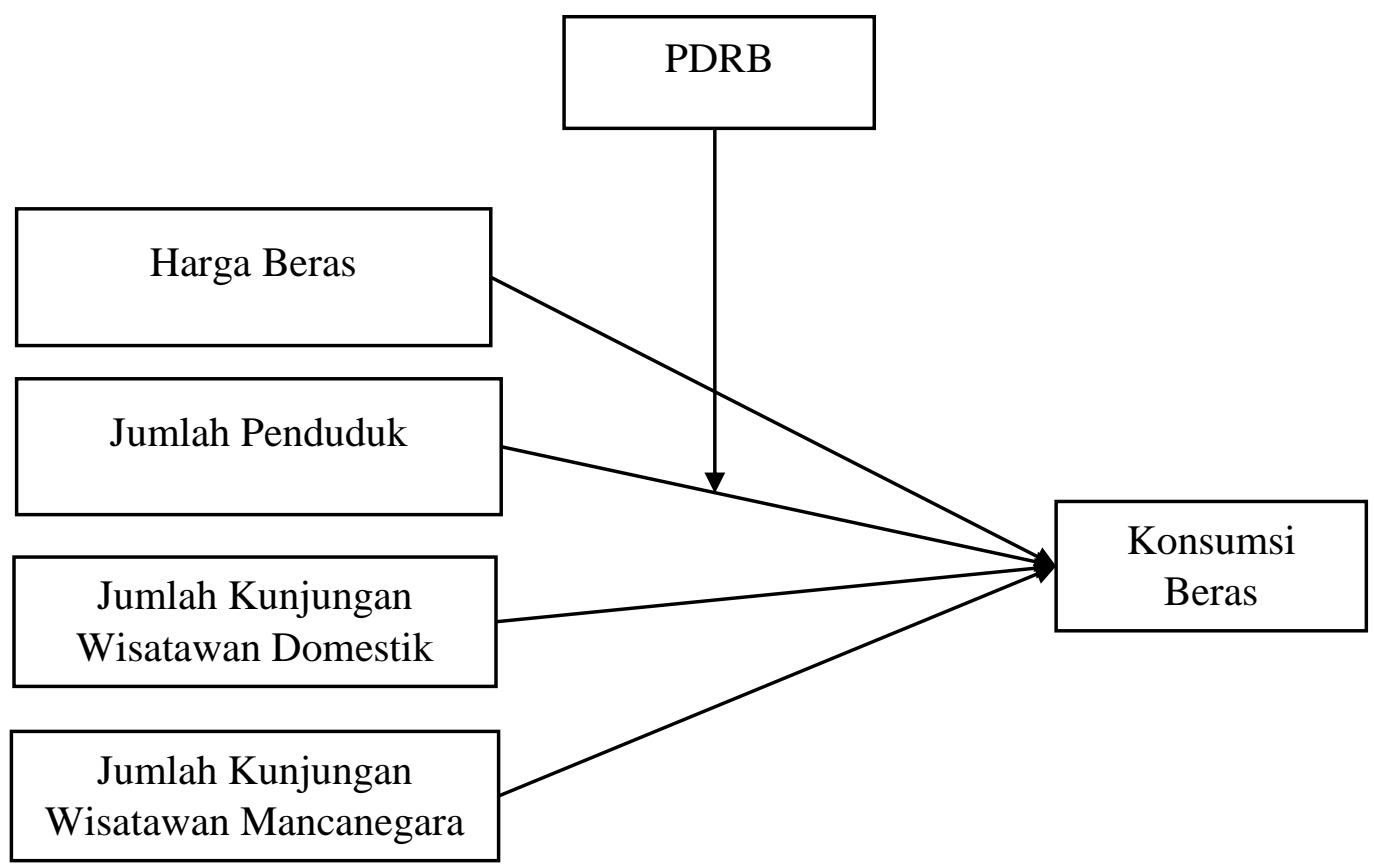

Gambar 1. Kerangka Konsep Penelitian

1) Pengaruh harga beras terhadap konsumsi beras

Berdasarkan studi yang dilakukan oleh Sari (2007), mengenai analisis dampak kenaikan harga beras terhadap pola konsumsi beras rumah tangga, studi kasus di Cipinang Jakarta Timur. Beras merupakan makanan pokok penduduk Indonesia dan belum ada bahan pangan lain yang secara utuh dapat menggantikannya, sehingga setinggi apapun harga beras, rumah tangga akan tetap berusaha untuk memenuhi kebutuhannya terhadap beras walaupun harus mengurangi jumlah konsumsi berasnya. Beras sebagai kebutuhan yang menyangkut hajat hidup orang banyak memang seharusnya lebih mendapat perhatian, khususnya harga sehingga tidak terjadi monopoli atau permainan harga yang dapat mengganggu kestabilan konsumsi beras di pasar. 
Kajian yang dilakukan oleh Sitepu (2002) mengenai dampak kebijakan ekonomi dan liberalisasi perdagangan terhadap penawaran dan permintaan beras di Indonesia menunjukkan bahwa respon produksi terhadap harga inelastis, baik jangka panjang maupun jangka pendek. Hal ini menunjukkan bahwa harga bukanlah faktor utama dalam peningkatan produksi. Sedangkan untuk permintaan beras untuk konsumsi dipengaruhi secara nyata oleh perubahan harga eceran beras, namun responnya inelastis artinya perubahan harga beras hanya berdampak kecil pada perubahan permintaan beras karena masyarakat Indonesia sulit menggantikan beras sebagai makanan pokok.

2) Pengaruh jumlah penduduk terhadap konsumsi beras

Keberadaan penduduk di suatu wilayah merupakan suatu potensi yang dapat dimanfaatkan bagi pembangunan wilayah tersebut. Jika dipandang dari sisi permintaan, penduduk merupakan peningkatan potensi pasar bagi produksi yang dihasilkan apabila pertumbuhan penduduk tersebut diiringi dengan peningkatan daya beli. Menurut Mangahas (dalam Benu, 1996), bahwa terdapat kenyataan dimana jumlah penduduk merupakan determinan utama dari kenaikan dalam permintaan produk pertanian. Sehingga jika suatu wilayah dengan kebutuhan pangan pokoknya adalah beras, maka peningkatan jumlah penduduk akan semakin meningkatkan permintaan terhadap beras.

Dalam penelitian yang dilakukan Nani (2009) di Kabupaten Siak, Riau menyatakan peningkatan jumlah penduduk berpengaruh terhadap peningkatan konsumsi beras domestik, dan dari hasil elastisitas jangka panjang yang mendekati satu menunjukkan bahwa dalam jangka panjang pertambahan 
penduduk merupakan faktor penting penyebab peningkatan konsumsi beras domestik. Hal ini disebabkan jagung bukan merupakan komoditi yang bersubstitusi terhadap padi, tetapi komoditi yang berkomplementer.

3) Pengaruh jumlah kunjungan wisatawan domestik terhadap konsumsi beras Alegre dan Cladera (2012) mengatakan bahwa setiap pengeluaran wisatawan pada suatu daerah tujuan wisata akan mendorong kegiatan ekonomi di daerah tujuan wisata yang dikunjungi. Sesuai dengan hal tersebut konsumsi wisatawan biasanya menyebabkan peningkatan output, harga dan upah di sektor yang menjual barang dan jasa kepada wisatawan. Sujai (2011) mengatakan sektorsektor yang memiliki keterkaitan langsung dengan kegiatan pariwisata antara lain adalah agen perjalanan, operator wisata, hotel, restoran, dan perdagangan eceran. Hotel dan restoran menjadi sarana penting dalam menunjang kegiatan wisata, karena hal ini terkait dengan kebutuhan konsumsi atas makanan dan tempat tinggal untuk wisatawan. Menurut Angappapillai (2013) konsumsi atas pangan atau makanan oleh wisatawan akan memberi dampak langsung terhadap konsumsi agregat, khususnya makanan pokok, jika dikaitkan dengan wisatawan domestik maka konsumsi beras akan meningkat seiring dengan peningkatan jumlah wisatawan.

4) Pengaruh jumlah kunjungan wisatawan mancanegara terhadap konsumsi beras

Wisatawan yang datang berkunjung di suatu daerah membuat peremintaan akan hasil daerah setempat meningkat. Misalnya saja permintaan akan barang 
kerajinan, handicraft, souvenir, serta barang yang khas dari daerah tersebut, seperti kain tenun, sulaman, minuman ataupun makanan khas daerah tersebut. Sebagaimana telah diungkapkan, pariwisata merupakan fenomena perjalanan orang - orang dari tempat asalnya ke tempat lain dengan tujuan bersenang senang (pleasure), dan untuk memanfaatkan waktu luang (leisure), memerlukan layanan yang dapat menggantikan apa yang biasa dinikmati di tempat tinggal mereka kesehariannya. Dari sinilah awal perilaku konsumsi wisatawan muncul.

Adanya wisatawan mancanegara yang berkunjuang ke suatu daerah dapat berarti suatu tambahan penduduk di daerah tersebut yang akan meningkatkan konsumsi agregat pada daerah tersebut. Wisatawan yang berasal dari Negara lain memiliki kebutuhan pangan pokok yang belum tentu sama dengan daerah yang ia kunjungi, kebutuhan tersebut akan disesuaikan dengan keberadaan wisatawan itu sendiri, hal ini karena terkait dengan ketersediaan di daerah tersebut. Menurut Mewa dan Haryono (2016) rata - rata kebutuhan pangan pokok beras perhari untuk wisatawan atau warga Negara asing di Indonesia tidak berbeda dengan masyarakat Indonesia, hal ini karena warga Negara asing tidak terbiasa dalam mengkonsumsi nasi dan cenderung mengkonsumsi olahan beras lainnya.

Perilaku konsumsi wisatawan terletak pada kegiatan atau aktivitas yang dilakukannya. Dalam konteks ini, perilaku wisatawan adalah kebutuhan manusia yang sedang dalam perjalanan mencari kesenangan, jauh dari tempat tinggalnya, dan semata- mata sebagai konsumen di daerah tujuan wisata yang dikunjunginya. Secara umum, kebutuhan manusia itu bertingkat, dimulai dari tingkat yang paling rendah hingga tingkat yang paling tinggi, dan selalu tidak ada batas serta bersifat 
sangat relatif. Dalam hal ini tentunya yang menjadi kebutuhan utama wisatawan yaitu pangan pokok.

5) Produk Domestik Regional Bruto (PDRB) memoderasi pengaruh harga beras terhadap konsumsi beras

Susanti (2000) menyatakan semakin besar Produk Domestik Regional Bruto (PDRB) di suatu daerah, semakin besar tingkat rata-rata konsumsi untuk barang dan jasa di daerah tersebut, khususnya untuk konsumsi pangan pokok. Meningkatnya kesejahteraan masyarakat yang dicerminkan dari PDRB tentunya mendorong perubahan pola konsumsi masyarakat ke arah yang lebih baik. Peningkatan pendapatan dapat meningkatkan konsumsi pangan pokok di masyarakat walaupun harganya cenderung meningkat. Karena pangan pokok merupakan kebutuhan utama manusia untuk dapat bertahan hidup, tentunya harus tetap terjamin ketersediaann dan harganya.

Menurut Sitepu (2002) berdasarkan hasil penelitiannya menyatakan bahwa peningkatan konsumsi dipengaruhi oleh peningkatan pendapatan dalam hal ini Produk Domestik Regional Bruto (PDRB) di suatu daerah serta harga, karena perubahan tingkat konsumsi masyarakat akan mempengaruhi harga sehingga daya beli masyarakat akan ditentukan oleh tingkat pendapatannya. Sejalan dengan Sitepu, Afrianto (2010), meningkatnya konsumsi beras dan adanya defisit produksi beras, tentunya akan menyebabkan adanya kenaikan harga beras di pasaran. Ketika harga beras mengalami kenaikan dan diimbangi dengan meningkatnya pendapatan maka masyarakat akan berusaha untuk membeli beras, 
hal ini karena masih sulit menggantikan beras dengan makanan lain sebagai makanan pokok atau sumber karbohidrat.

6) Produk Domestik Regional Bruto (PDRB) memoderasi pengaruh jumlah penduduk terhadap konsumsi beras

Meningkatnya jumlah penduduk berarti meningkatnya potensi pasar dan jumlah konsumen (Sadono Sukirno, 2003). Menurut Pasomba (2016) peningkakatan jumlah penduduk yang diiringi dengan meningkatnya PDRB akan meningkatkan konsumsi masyarakat. Meningkatnya PDRB mengindikasikan adanya peningkatan aktivitas perekonomian masyarakat sehingga mendorong peningkatan kesejahteraan masyarakat. Jika dikaitkan dengan konsumsi beras yang merupakan makanan pokok maka meningkatnya jumlah penduduk tentunya dapat meningkatkan konsumsi beras secara agregat pada suatu wilayah.

Faktor Produk Domestik Regional Bruto (PDRB) yang mendorong peningkatan kesejahteraan masyarakat merupakan salah satu faktor penting yang mempengaruhi pola konsumsi rumah tangga. PDRB yang semakin tinggi menunjukkkan daya beli yang semakin meningkat, dan meningkat pula aksesibilitas terhadap pangan yang berkualitas baik (Rinanda, 2010). Senada dengan Ritonga (2004), mengungkapkan bahwa rendahnya elastisitas harga beras memberikan petunjuk bahwa usaha mempertahankan harga beras tidak banyak berpengaruh terhadap konsumsi beras. Konsumsi beras lebih ditentukan oleh pertumbuhan penduduk dan peningkatan pendapatan daripada perubahan harga. Hal ini disebabkan karena beras merupakan makanan pokok masyarakat Indonesia yang sulit digantikan dengan barang lain. 


\section{Hipotesis Penelitian}

Berdasarkan uraian kerangka berpikir diatas, maka hipotesis dalam penelitian ini dapat dijabarkan sebagai berikut:

1) Jumlah penduduk, jumlah kunjungan wisatawan domestik dan jumlah kunjungan wisatawan mancanegara berpengaruh positif sedangkan harga beras berpengaruh negatif terhadap konsumsi beras di Provinsi Bali

2) Produk Domestik Regional Bruto (PDRB) memperkuat pengaruh harga beras dan jumlah penduduk terhadap konsumsi beras di Provinsi Bali

\section{Metode Penelitian}

Dalam penelitian ini menggunakan data sekunder untuk dianalisi selama periode tahun 1983-2016 yang diperoleh dari Badan Pusat Statistik (BPS), Dinas Pertanian Provinsi Bali, Dinas Pariwisata Provinsi Bali, BULOG Provinsi Bali, dll. Untuk menganalisis pengaruh harga beras, jumlah penduduk, jumlah kunjungan wisatawan domestik, jumlah kunjungan wisatawan mancanegara, Produk Domestik Regional Bruto (PDRB) terhadap konsumsi beras dalam penelitian ini diterapkan metode analisis regresi linier berganda dan Regresi Variabel Moderating (MRA). Persamaan yang dibentuk di dalam penelitian ini adalah:

1) Konsumsi Beras

a) Analisis regresi linier berganda

$Y=\beta_{1} X_{1}+\beta_{2} X_{2}+\beta_{3} X_{3}+\beta_{4} X_{4}+e$ 
b) Analisis variabel moderating

$\mathrm{Y}=\beta_{1} \mathrm{ZX}_{1}+\beta_{2} \mathrm{ZX}_{2}+\beta_{3} \mathrm{ZX}_{5}+\beta_{4}\left|\mathrm{ZX}_{1}-\mathrm{ZX}_{5}\right|+\beta_{5}\left|\mathrm{ZX}_{2}-\mathrm{ZX}_{5}\right|+\mathrm{e}$

Keterangan :

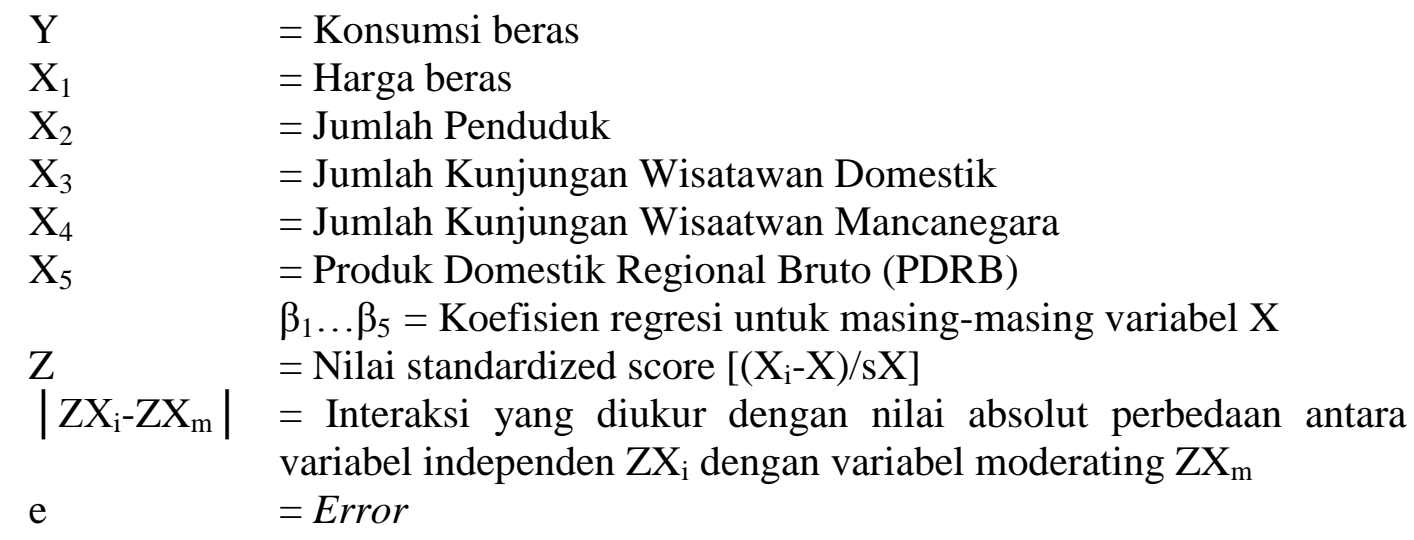

\section{Analisis Regresi Linier Berganda Dan Analisis Variabel Moderating}

Setelah data hasil penelitian terkumpul dilakukan analisis data dengan program Statistical Product and Service Solution (SPSS), dan hasilnya adalah sebagai berikut :

\section{Tabel 1. Analisis Regresi Linier Berganda}

\begin{tabular}{lccc}
\hline \multicolumn{1}{c}{ Variabel } & $\mathrm{B}$ & $\mathrm{T}$ & Sig. \\
\hline Constant & 232260,400 & 5,803 & 0,000 \\
Harga Beras & $-4,708$ & 1,737 & 0,860 \\
Jumlah Penduduk & 0,046 & 4,069 & 0,000 \\
Jumlah Kunjungan Wisatawan Domestik & 0,008 & 2,380 & 0,007 \\
Jumlah Kunjungan Wisatawan Mancanegara & 0,004 & 1,916 & 0,005 \\
& $\mathrm{R}^{2}=0,676$ & $\mathrm{~F}=15,159$ & \\
\hline
\end{tabular}

Dari persamaan tersebut dapat diketahui bahwa jumlah penduduk $\left(\mathrm{X}_{2}\right)$, jumlah kunjungan wisatawan domestik $\left(\mathrm{X}_{3}\right)$ dan jumlah kunjungan wisatawan mancanegara $\left(\mathrm{X}_{4}\right)$ berpengaruh positif dan siginifikan terhadap konsumsi beras Provinsi Bali pada tahun 1983-2016 dengan nilai signifikansi dibawah 0,05. Sedangkan harga beras $\left(\mathrm{X}_{1}\right)$ berpengaruh negatif namun tidak signifikan terhadap 
konsumsi beras dengan nilai signifikansi diatas 0,05. Jika dilihat secara umum, harga beras $(\mathrm{X} 1)$,jumlah penduduk $\left(\mathrm{X}_{2}\right)$, jumlah kunjungan wisatawan domestik $\left(\mathrm{X}_{3}\right)$ dan jumlah kunjungan wisatawan mancanegara $\left(\mathrm{X}_{4}\right)$ mempengaruhi 67,6 persen konsumsi beras, sedangkan 32,3 persen diperkirakan dipengaruhi oleh variabel lain yang tidak dimasukan atau diteliti dalam penelitian ini dengan asumsi variabel lainnya konstan.

Tabel 2. Analisis Regresi Variabel Moderating

\begin{tabular}{|c|c|c|c|}
\hline Variabel & B & $\mathrm{t}$ & Sig. \\
\hline Constant & 303476,600 & 23,840 & 0,000 \\
\hline AbsX1_X5 & 5261,290 & 2,114 & 0,010 \\
\hline AbsX2_X5 & $\begin{array}{c}9416,399 \\
\mathrm{R}^{2}=0,751\end{array}$ & $\begin{array}{c}2,927 \\
\mathrm{~F}=16,917\end{array}$ & 0,007 \\
\hline
\end{tabular}

Dari persamaan tersebut dapat diketahui bagaimana Produk Domestik Regional Bruto $(\mathrm{PDRB})\left(\mathrm{X}_{5}\right)$ memperkuat pengaruh harga beras $\left(\mathrm{X}_{1}\right)$ dan jumlah penduduk $\left(\mathrm{X}_{2}\right)$ terhadap konsumsi beras $(\mathrm{Y})$ di Provinsi Bali pada tahun 19832016. Hal ini dibuktikan dengan nilai signifikansi masing - masing nilai absolut residual berada dibawah 0,05 . Hal ini semakin diperkuat dengan nilai $\mathrm{R}^{2}$ sebesar 75,1 persen, lebih besar dari nilai $\mathrm{R}^{2}$ analisis regresi berganda.

\section{Pembahasan}

Penelitian ini berfokus pada faktor - faktor yang mempengaruhi konsumsi beras di Provinsi Bali, seperti harga beras, jumlah penduduk, jumlah kunjungan wisatawan domestik, jumlah kunjungan wistawan mancanegara dan Produk Domestik Regional Bruto (PDRB). Secara deskriptif juga dijelaskan mengenai ketersediaan beras di Provinsi Bali untuk memperkaya informasi dan analisis yang dapat dikembangkan. 
I Putu Danendra Putra, dan I Gede Wardana. A nalisis Faktor-Faktor ...

1) Pengaruh Harga Beras Terhadap Konsumsi Beras

Dalam pengaruh harga beras terhadap konsumsi beras. Berdasarkan hasil analisis diatas menunjukan harga beras berpengaruh negatif dan tidak signifikan terhadap konsumsi beras. Pada konsumsi beras, ketika harga meningkat konsumsi beras akan mengalami penurunan namun tidak signifikan, hal ini dikarenakan beras merupakan barang yang bersifat inelastis. Pada hasil analisis jika terjadi kenaikan harga beras sebesar Rp. 1000 maka konsumsi beras akan turun sebesar 4,708 ton namun tidak signifikan dengan asumsi variabel lainnya konstan. Hal ini disebabkan karena beras merupakan makanan pokok masyarakat Bali yang masih sulit digantikan oleh jenis sumber karbohidrat lainnya, dimana pada terori Simon Kuznet, rasio perbandingan antara konsumsi dengan pendapatan ternyata cenderung stabil dari tahun ke tahun, meskipun pendapatan masyarakat mengalami peningkatan.

Menurut Dragan (2010) konsumsi masyarakat untuk memenuhi kebutuhan akan makanan cenderung tetap. Ketika ada kenaikan harga, masyarakat akan tetap mengkonsumsi makanan pokoknya, meskipun terdapat barang pengganti yang serupa yang lebih murah, masyarakat masih tetap berusaha memenuhi pahan pokok utamanya terlebih dahulu. Menurut Rosemary (2013) harga makanan akan meningkat seiring dengan peningkatan konsumsi khsusnya pada makanan pokok. Pada konsumsi makanan pokok, konsumen tidak akan mengganti atau beralih sepenuhnya ke jenis makanan lain ketika harga meningkat, konsumen akan cenderung menurunkan sedikit konsumsinya sesai dengan kemampuannya. Hal ini 
desebabkan sangat sulit menggantikan makanan pokok dengan jenis makanan lain, meskipun kandungan gizi di dalamnya hampir sama.

Pada penelitian yang dilakukan oleh Sari (2007), penduduk Indonesia dalam memenuhi kebutuhannya akan energi mengkonsumsi beras sebagai makanan pokok. Beras sebagai makan pokok fungsinya belum dapat digantikan oleh bahan pangan lainnya secara utuh, sehingga meskipun harga beras tinggi, masyarakat akan tetap membeli beras untuk memenuhi kebutuhannya meskipun harus mengurangi jumlah konsumsi berasnya. Beras yang dibutuhkan oleh 90 persen penduduk Indonesia memang seharusnya lebih mendapat perhatian, khususnya harga sehingga tidak terjadi monopoli atau permainan harga yang dapat mengganggu kestabilan konsumsi beras di pasar.

\section{2) Pengaruh Jumlah Penduduk Terhadap Konsumsi Beras}

Pada hasil analisis jumlah penduduk terhadap konsumsi beras menunjukan pengaruh positif dan signifikan. Penduduk merupakan orang yang tinggal di suatu wilayah dalam kurun waktu lebih dari enam bulan di Provinsi Bali. Dalam kaitannya dengan perekonomian, penduduk merupakan sumber daya ekonomi yang paling penting, baik itu dalam proses produksi, distribusi maupun konsumsi. Bila berfokus pada kegiatan konsumsi, penduduk merupakan potensi pasar, dimana semakin tinggi jumlah penduduk maka semakin besar juga pangsa pasarnya. Dalam kaitannya dengan konsumsi beras, dimana beras merupakan kebutuhan pokok dan paling asasi bagi manusia tentunya beras memiliki pangsa pasar yang paling besar, sehingga naik turunnya jumlah penduduk akan berpengaruh terhadap konsumsi beras. 
Pada hasil penelitian ini diperoleh hasil bahwa jumlah penduduk berpengaruh positif dan signifikan terhadap konsumsi beras, dimana ketika jumlah penduduk meningkat sebanyak 1 orang maka konsumsi beras akan meningkat sebesar 0,046 ton setiap tahunnya dengan asumsi variabel lainnya konstan. Meningkatnya konsumsi beras seiring dengan meningkatnya jumlah penduduk disebabkan karena beras merupakan makanan pokok masyarakat Bali yang masih sulit digantikan oleh jenis sumber karbohidrat lainnya. Hal tersebut senada dengan Marija (2017) dimana pertumbuhan jumlah penduduk akan meningkatkan konsumsi beras, hal ini disebabkan penduduk baru baik itu oleh kelahiran ataupun pendatang akan selalu berusaha untuk menjamin kebutuhan gizinya guna menjaga kesehatannya. Senada dengan Nguyen (2010) konsumsi pangan terus mengalami peningkatan seiring dengan meningkatnya jumlah penduduk, khsusunya meningkatnya jumlah penduduk karena migrasi, hal ini karena jumlah penduduk migrasi cenderung bisa lebih banyak daripada penduduk lokal atau pertumbuhan penduduk alamiah.

Dalam penelitian yang dilakukan Nani (2009) menyatakan meningkatnya jumlah penduduk akan berpengaruh terhadap meningkatnya konsumsi beras domestik, berdasarkan hasil elastisitas dalam jangka panjang yang nilainya mendekati satu yang berarti bahwa dalam jangka panjang pertambahan penduduk merupakan faktor dominan yang mempengaruhi meningkatnya konsumsi beras domestik. Meningkatnya konsumsi beras akibat dari bertambahnya jumlah penduduk tentunya harus mendapat perhatian khusus dari pemerintah, baik itu oleh pemerintah pusat ataupun pemerintah daerah. Menurut 
Pasomba (2016) dalam upaya pemenuhan kebutuhan pokok masyarakat khsusnya beras ditengah pesatnya pertumbuhan jumlah penduduk perlu adanya upaya dalam peningkatan produksi dan pemetaan produksi dan konsumsi beras di masa depan.

3) Pengaruh Jumlah Kunjungan Wisatawan Domestik Dan Mancanegara Terhadap Konsumsi Beras

Pada hasil anaslis untuk jumlah kunjungan wisatawan domestik dan jumlah kunjungan wisatawan mancanegara masing - masing berpengaruh positif dan signifikan terhadap konsumsi beras. Dimana jika jumlah kunjungan wisatawan domestik meningkat 1 orang maka konsumsi beras di Provinsi Bali akan meningkat sebesar 0,008 ton setiap tahunnya, sedangkan jika jumlah kunjungan wisatawan mancanegara meningkat 1 orang maka konsumsi beras agregat Provinsi Bali akan meningkat sebesar 0,004 ton setiap tahunnya dengan asumsi variabel lainnya konstan. Menurut Mewa dan Haryono (2016) rata rata kebutuhan pangan pokok beras perhari untuk wisatawan atau warga Negara asing di Indonesia tidak berbeda dengan masyarakat Indonesia, hal ini karena warga Negara asing tidak terbiasa dalam mengkonsumsi nasi dan cenderung mengkonsumsi olahan beras lainnya.

Menurut Athena (2015) wisatawan yang berkunjunga ke suatu daerah akan berdampak langsung terhadap konsumsi di daerah kunjungan, khususnya makanan pokok. Wisatawan tentunya memiliki kebutuhan akan makanan yang harus tetap dipenuhi dimanapun mereka berada, oleh sebab itu kemampuan suatu daerah dalam menyediakan akomodasi pariwisata yang lengkap akan menentukan kepuasan wistawan. Meningkatnya konsumsi 
beras wisatawan dipengaruhi oleh jumlah kunjungan wisatawan dan rata-rata lama tinggal wisatawan di Bali. Hasil penelitian ini sesuai dengan penelitian Angappapillai (2013), dimana konsumsi atas pangan atau makanan oleh wisatawan akan memberi dampak langsung terhadap konsumsi agregat, khususnya makanan pokok.

4) Analisis Produk Domestik Regional Bruto (PDRB) Memperkuat Pengaruh Harga Beras Dan Jumlah Penduduk Terhadap Konsumsi Beras

Analisis Produk Domestik Regional Bruto (PDRB) menunjukan memperkuat pengaruh harga beras dan jumlah penduduk terhadap konsumsi beras. Susanti (2000) menyatakan semakin besar Produk Domestik Regional Bruto (PDRB) di suatu daerah, semakin besar tingkat rata-rata konsumsi untuk barang dan jasa di daerah tersebut, khususnya untuk konsumsi pangan pokok. Meningkatnya kesejahteraan masyarakat yang dicerminkan dari PDRB tentunya mendorong perubahan pola konsumsi masyarakat ke arah yang lebih baik. Peningkatan pendapatan dapat meningkatkan konsumsi pangan pokok di masyarakat walaupun harganya cenderung meningkat.

Senada dengan Lestari (2014) yang menyatakan konsumsi beras yang semakin meningkat harus dapat dijaga kestabilan ketersedian dan harganya. Meningkatnya perekonomian daerah yang dilihat dari pertumbuhan Produk Domestik Regional Bruto (PDRB) akan berdampak juga pada peningkatan pendapatan masyarakat yang mendorong peningkatan konsumsi beras dalam rangka perbaikan gizi masyarakat. Karena pangan pokok merupakan kebutuhan 
utama manusia untuk dapat bertahan hidup, tentunya harus tetap terjamin ketersediaan dan harganya. Meningkatnya jumlah penduduk berarti meningkatnya potensi pasar dan jumlah konsumen (Sadono Sukirno, 2003).

Menurut Pasomba (2016) peningkakatan jumlah penduduk yang diiringi dengan meningkatnya PDRB akan meningkatkan konsumsi masyarakat. Meningkatnya PDRB mengindikasikan adanya peningkatan aktivitas perekonomian masyarakat sehingga mendorong peningkatan kesejahteraan masyarakat. Jika dikaitkan dengan konsumsi beras yang merupakan makanan pokok maka meningkatnya jumlah penduduk tentunya dapat meningkatkan konsumsi beras secara agregat pada suatu wilayah. Faktor Produk Domestik Regional Bruto (PDRB) yang mendorong peningkatan kesejahteraan masyarakat tentunya akan mempengaruhi pola konsumsi rumah tangga. PDRB yang semakin tinggi mengindikasikan daya beli masyarakat yang semakin meningkat, dan meningkat pula kemampuan masyarakat dalam mengakses pangan yang lebih berkualitas baik (Rinanda, 2010). Senada dengan Ritonga et all (1989) dalam Ritonga (2004), menyatakan elastisitas harga beras yang rendah mengindikasikan upaya untuk mengendalikan harga beras tidak banyak mempengaruhi konsumsi beras. Konsumsi cenderung dipengaruhi oleh peningkatan pendapatan dan meningkatnya jumlah penduduk daripada perubahan harga. Hal ini disebabkan karena beras merupakan makanan pokok masyarakat Indonesia yang sulit digantikan dengan barang lain.

\section{5) Rasio Ketersediaan Beras Provinsi Bali}


I Putu Danendra Putra, dan I Gede Wardana. A nalisis Faktor-Faktor ...

Tabel 3. Selisih Ketersediaan Beras Provinsi Bali Tahun 2010-2016

\begin{tabular}{cccccc}
\hline Tahun & $\begin{array}{c}\text { Konsumsi } \\
\text { Beras (Ton) }\end{array}$ & $\begin{array}{c}\text { Produksi } \\
\text { Beras (Ton) }\end{array}$ & $\begin{array}{c}\text { Selisih } \\
\text { (Ton) }\end{array}$ & $\begin{array}{c}\text { Beras Impor \& } \\
\text { Luar Bali (Ton) }\end{array}$ & $\begin{array}{c}\text { Ketersediaan } \\
\text { Akhir (Ton) }\end{array}$ \\
\hline 2010 & 426.147 & $490.847,4$ & $64.700,4$ & 26.601 & $517.448,4$ \\
2011 & $433.938,5$ & $483.888,7$ & $49.950,2$ & 35.637 & $519.525,7$ \\
2012 & $439.236,1$ & $488.048,6$ & $48.812,5$ & 33.806 & $521.854,6$ \\
2013 & $445.819,6$ & $464.266,3$ & $18.446,8$ & 34.227 & $498.493,3$ \\
2014 & $451.058,2$ & $461.644,2$ & $10.586,1$ & 41.682 & $503.326,2$ \\
2015 & $458.024,6$ & $445.759,3$ & $-12.265,3$ & 24.145 & $469.904,3$ \\
2016 & $468.694,8$ & $448.844,5$ & $-19.850,3$ & 36.981 & $485.825,5$ \\
\hline
\end{tabular}

Sumber: Badan Pusat Statistik (BPS) dan Dinas Pertanian Provinsi Bali

Pada tahun 2010, selisih konsumsi beras dengan ketersediaan beras sebesar $64.700,4$ ton dan terus menurun drastis hingga tahun 2016, dengan selisih $-19.850,3$ ton atau mengalami defisit. Melalui peran BULOG dalam menjaga ketersediaan beras, mendatangkan beras dari luar Bali dan impor sejak tahun 2010, sehingga ketersediaan beras dapat terjaga dan tidak terjadi defisit. Tidak terjadinya defisit ketersediaan beras di tahun 2016 dapat dilihat pada selisih akhir menjadi surplus $17.130,7$ ton. Peranan pemerintah melalui (BULOG) dalam upaya untuk memantau, menstabilkan harga dan menjaga ketersediaan beras di pasar belum mapu berperan secara maksimal akibat dari masih lemahnya kemampuan manajerial pengelola lembaga tersebut sehingga sering terjadi defisit ketersediaaan beras sehingga menyebabkan kenaikan harga beras di pasar yang cukup meresahkan masyarakat (Husni, 2004).

Terjaganya ketersediaan beras tidak menjamin adanya harga yang tetap atau bahkan penurunan harga, yang terjadi justru peningkatan harga beras setiap tahunnya. Meningkatnya harga beras setiap tahunnya tidak lepas 
dari terus meningkatnya konsumsi beras dan menurunnya produksi beras di Provinsi Bali, selain itu, karena adanya inflasi juga menyebabkan harga terus meningkat. Dalam menjaga harga agar tetap masih pada jangkauan kemampuan masyarakat, pemerintah menerapkan kebijakan harga batas bawah dan batas atas. Pemerintah selain menerapkan batas harga juga melakukan operasi pasar saat terjadi gejolak harga beras dipasar, hal ini dilakukan dengan cara memberi subsidi secara langsung pada masyarakat, sehingga diharapkan harga beras dapat pulih kembali.

Kajian yang dilakukan oleh Sitepu (2002) mengenai dampak kebijakan ekonomi dan liberalisasi perdagangan terhadap penawaran dan permintaan beras di Indonesia menunjukkan bahwa respon produksi terhadap harga inelastis, baik jangka panjang maupun jangka pendek. Hal ini menunjukkan bahwa harga bukanlah faktor utama dalam peningkatan produksi. Sedangkan untuk permintaan beras untuk konsumsi dipengaruhi oleh perubahan harga eceran beras, namun responnya inelastis artinya perubahan harga beras hanya berdampak kecil pada perubahan permintaan beras karena masyarakat Indonesia sulit menggantikan beras sebagai makanan pokok.

Penurunan produksi beras tentunya tidak sesuai dengan salah satu tujuan pemerintah baik pusat maupun daerah dalam kaitannya dengan ketahanan pangan dengan cara menciptakan swasembada pangan. Penurunan produksi padi atau beras dapat mengakibatkan harga beras semakin tinggi bahkan harga barang lainnya juga bisa meningkat, hal ini tentunya akan meresahkan masyarakat, 
karena konsumsi beras terus meningkat. Dalam upaya memenuhi kurangnya produksi padi atau beras diperlukannya berbagai upaya untuk dapat meningkatkan hasil produksi padi atau beras di Bali demi terpenuhinya kebutuhan bahan pangan beras dan menciptakan swasembada beras di Bali maupun di Indonesia.

\section{Simpulan dan Saran}

Jumlah penduduk, jumlah kunjungan wisatawan domestik dan jumlah kunjungan wisatawan mancanegara berpengaruh positif dan signifikan terhadap konsumsi beras, sedangkan harga beras berpengaruh negatif namun tidak signifikan terhadap konsumsi beras Provinsi Bali tahun 1983-2016. Produk Domestik Regional Bruto (PDRB) secara signifikan memperkuat pengaruh harga beras dan jumlah penduduk terhadap konsumsi beras Provinsi Bali tahun 1983-2016.

Berdasarkan hasil penelitian, penulis berharap pemerintah Provinsi Bali dapat meningkatkan produksi beras di Bali khususnya dengan cara mempertegas dan memperluas lahan pertanian, membangun saluran irigasi, memproteksi harga gabah serta pemanfaatan teknologi pertanian. Melalui hal ini diharapkan produksi beras Bali meningkat dan swasembada beras dapat tercapai mengingat konsumsi beras terus meningkat. Meningkatnya jumlah penduduk dan kunjungan wisatawan setiap tahun terus meningkatkan konsumsi beras. Hal ini harusnya dapat lebih diperhatikan, khususnya dalam pemerataan distribusi guna dapat menjaga ketersediaan beras untuk bernagai kebutuhan. Semakin berkembangnya perekonomian di Provinsi Bali yang ditunjukan oleh terus meningkatnya Produk Domestik Regional Bruto 
(PDRB) menyebabkan kesejahteraan masyarakat semakin meningkat, khsusnya pada masyarakat yang sebelumnya tergolong miskin. Hal ini menyebabkan konsumsi agregat juga meningkat, khususnya konsumsi beras sebagai makanan pokok. Dalam upaya menjaga tingkat kesejahteraan masyarakat, hendaknya pemerintah benar-benar menjaga ketersediaan beras, khsusnya untuk masyarakat yang tergolong miskin, sehingga tidak terjadi kenaikan harga yang dapat menurunkan tingkat kesejahteraan masyarakat. Dalam mengambil kebijakan pemerintah Provinsi Bali diharapkan dapat bertindak cepat. Melalui prediksi yang akurat dan gejala-gejala yang terjadi di pasar beras hendaknya dapat dijadikan acuan dalam mengambil keputusan yang cepat terkait dalam ketersediaan beras, baik itu mendatangkan beras dari luar daerah atau impor.

\section{Daftar Pustaka}

Afrianto, Denny. 2010. Analisis Pengaruh Stok Beras, Luas Panen, Rata-Rata Produksi, Harga Beras, dan Jumlah Konsumsi Beras Terhadap Ketahanan Pangan di Jawa Tengah (Skripsi). Semarang: Fakultas Ekonomi Universitas Diponegoro

Alegre, Joaquín., and Cladera, Magdalena. 2012. Tourist characteristics that influence shopping participation and expenditures. International Journal of Culture, Tourism and Hospitality Research, 6(3), pp:223-237.

Amang, B dan Sawit, M.H. 1999. Kebijakan Beras dan Pangan Nasional Pelajaran dari Orde Baru dan Era Reformasi. Jakarta: IPB Press.

Anggappapillai, A B. and Shanmugasundram, N. 2013. The Impact Of Tourism On Expenditure Portfolio and Its Determinant. International Journal of Management Research and Reviews,3(6), pp:3006-3015. 
Athena H.N. Mak, Margaret Lumbers. 2015. Factors Influencing Tourist Food Consumption. Journal. University of Surrey, UK.

Benu, F.L. 1996. Analisis Struktur Produksi, Konsumsi dan Perdagangan Beras di Provinsi Nusa Tenggara Timur. Tesis. Program Pasca Sarjana. Institut Pertanian Bogor, Bogor.

Badan Pusat Statistik Provinsi Bali. 2016. Bali Dalam Angka Tahun 2016 : BPS Provinsi Bali

Dragan Miljkovic, Cary Effertz. 2010. Consumer Behavior In Food Consumption: Reference Price Approach. British Food Journal, Vol. 112 Issue: 1, pp.3243, https://doi.org/10.1108/00070701011011182

Lestari Lisa. 2014. Faktor - Faktor Yang Mempengaruhi Ketersediaan Dan Konsumsi Pangan Strategis (Beras Dan Cabai) Di Sumatera Utara. Jurnal Agribisnis. Universitas Sumatra Utara.

Mankiw, N.Gregory. (2007). Teori Makro Ekonomi. Jakarta. Erlangga

Marija Knez, Marina Nikolic. 2017. The Influence Of Food Consumption And Socio-Economic Factors On The Relationship Between Zinc And Iron Intake And Status In a Healthy Population. https://doi.org/10.1017/S1368980017001240 (Diakses 8 Desember 2017)

Mewa, Haryono. 2016. Daya Saing Produk Pertanian Indonesia. http://www.litbang.pertanian.go.id/buku/memperkuat_dayasaing_produk pe/BAB-III-13.pdf. Diakses 26 Juli 2017.

Mickael B. Hoelman, Bona Tua Parlinggoman Parhusip, Sutoro Eko. 2015. Panduan SDGs (Sustainable Development Goals) Untuk Pemerintah Daerah (Kota dan Kabupaten). International Forum On Indonesian Development. Jakarta

Nani Sunani. 2009. Analisis Faktor- Faktor yang Mempengaruhi Produksi dan Konsumsi Beras di Kabupaten Siak, Riau. Skripsi Fakultas Ekonomi dan Manajemen Institut Pertanian Bogor

Nguyen, Minh Cong. 2010. The Impact of Migration on Food Consumption Patterns :The Case of Vietnam. 
E-Jurnal Ekonomi dan Bisnis Universitas Udayana 7.6 (2018): 1589-1616

https://www.sciencedirect.com/science/article/pii/S0306919210001156?vi a\%3Dihub. Diakses 5 Desember 2017

Pasomba Yudas. 2016. Analisis Pengaruh Perkembangan Penduduk dan PDRB terhadap Tingkat Konsumsi Masyarakat yang ada di Melongguane. Jurnal Fakultas Ekonomi dan Bisnis Program Magister Ilmu Ekonomi.

Rinanda, Teja. 2010. Analisis Faktor-Faktor Yang Mempengaruhi Konsumsi Masyarakat di Provinsi Sumatera Utara. Tesis, USU, Medan.

Ritonga, E. 2004. Analisis Keefektifan Kebijakan Harga Dasar Beras. Tesis. Magister Sains Pascasarjana IPB. Bogor

Rosemary Green, Laura Cornelsen. 2013. The Effect Of Rising Food Prices On Food Consumption: Systematic Review With Meta-Regression. Journal. Faculty of Epidemiology and Population Health, London School of Hygiene and Tropical Medicine. BMJ 2013;346:f3703

Sari, N.T. 2007. Analisis dampak Kenaikan Harga Beras terhadap Pola Konsumsi Beras Rumah Tangga, di Cipinang Jakarta Timur. Skripsi. Fakultas Pertanian Institut Pertanian Bogor.

Sitepu, R.K. 2002. Dampak Kebijakan Ekonomi dan Liberalisasi Perdagangan terhadap Penawaran dan Permintaan Beras di Indonesia. Tesis Program Pasca Sarjana. Institut Pertanian Bogor, Bogor.

Sujai, Mahpud. 2011. Desentralisasi Fiskal dan Sektor Pariwisata Indonesia. Jurnal Kepariwisataan Indonesia, 6(1), h:15-26.

Sukirno, Sadono. 2003. Pengantar Ekonomi Mikro. Jakarta: Rajawali Press.

Suryana, A. 2008. Kebijakan dan Kendala Pengembanagn Sumberdaya Pangan.

Di dalam: Akuntansi Sumberdaya Alam: Pangan, Energi dan Air. Prosididng Seminar Nasional, Jakarta, 10 Desember. Jakarta. Badan Ketahanan Pangan. Departemen Pertanian.

Susanti, C Yuniar. 2000. Analisis Pengaruh PDRB Terhadap Jumlah Konsumsi Masyarakat di Provinsi Daerah Istimewa Aceh. Journal Ekonomi Pembangunan, Volume 6 Nomor 3 hal. 332345

Suyana, Utama. 2012. Aplikasi Analisis Kuantitatif. Fakultas Ekonomi dan Bisnis Universitas Udayana : Denpasar 
I Putu Danendra Putra, dan I Gede Wardana. A nalisis Faktor-Faktor ...

Suyana, Utama. 2013. Ekonometrika. Fakultas Ekonomi Universitas Udayana :

Denpasar 